\title{
Match Fixing Gratification In Football
}

\author{
Endah Lestari ${ }^{1}$ and Woro Winandi ${ }^{2}$ \\ \{woro.wianandi@narotama.ac.id ${ }^{2}$ \} \\ Narotama University ${ }^{1,2}$
}

\begin{abstract}
At the end of 2018 to January 2019, Indonesian football has been suffered by match fixing scandal of ensuring one of Indonesian league participants to be the winner. Such practice occurred during League 2 and League 3 matches in Central Java. This match fixing involving PSSI (The Indonesian Football Association) Executive Committees and Referee Committees tarnishes Indonesian Football image. The deed of match fixing in football can be categorized as criminal acts of corruption because gratification is obtained by the parties involved. Based on this background, this paper analyzes 2 problems, (1) Causes of match fixing in Football (2) Preventions and countermeasures efforts for Match fixing in Football
\end{abstract}

Keywords: Gratification; Match Fixing; Football

\section{Introduction}

Corruption is a never-ending problem discussed in Indonesia; the current economic state of the country, that is increasingly unstable coupled with the increase and disclosure of corruption cases, potentially harms the state. If this problem is neglected, it can lead to the deterioration of the country.

Corruption crimes may occur when opportunities, desires, and fall down of the monitoring system materialize at the same time. Corruption can be started anytime and anywhere, for example bribery is offered to an official, or to a certain extent that official becomes the one who is asking or even forcing the availability of the facilitation payments. People offer the bribes for desiring things which are not theirs; and the bribery to the officials make them ignore the rules.

The weak of law enforcement in corruption cases causes widespread of this crime in all fields, including in sports, especially football. Corruption crime is defined as the acts of not only enriching oneself or others but also providing pleasure to other people or certain groups which are usually referred to as gratification.

Gratification may be found within the bureaucracy system as well as other sectors including sports, one of which is football, especially in organizing football matches such as the Indonesian Football League (Liga Sepakbola Indonesia), hereinafter abbreviated as LSI.

In football, gratification occurs when match fixing involves various parties, such as referees, players, managers or administrators of football organizations in the match event, as happened in match fixing involving the board of PSSI (The Indonesian Football Association).

Based on background of the study described above, issues are formulated as follows (a) What are the causes of gratification in match fixing? And (b) 2. What are the prevention and countermeasures efforts for match fixing? 


\section{Discussion}

\subsection{Causes of gratification in match fixing}

Based on the decision of the judges of the Public Information Commissioner, The Indonesian Football Association (hereinafter abbreviated as PSSI) has been designated as a Public Organization because PSSI is an organization which receives funding from APBN (State Budget), even though PSSI is categorized as a Non-Government organization.

Under such circumstances, the use of PSSI fund as well as its management must be audited. Regarding PSSI as a Non Government organization, an interesting fact of its match fixing scandal is the involvement of PSSI committees; one of them is Joko Driyono as Acting Chairman of PSSI. Joko Driyono became Acting Chairman of PSSI replacing Edy Rahmayadi in the 2019 Bali Congress. Shortly after, Joko Driyono was dragged into match fixing case. He became a suspect for his involvement in tampering evidence. Currently, Joko is officially detained by the Football Anti Mafia Task Force.

Generally, the term corruption is described as:

"....Corruption is derived from Latin, corruptio, which means rotten, broken, shaky, twisting, bribing. Literally, corruption is the behavior of public officials, either politicians or civil servants who improperly and illegally enrich themselves or those close to them by abusing public power entrusted to them."[1]

Corruption is very disgraceful act and can harm a nation. Indonesia is one of the countries with a large number of corruption cases [2]. Corruption acts committed by public officials could be related to gratification and money laundering.

As far as is known, match fixing case in football matches involves gratification which is criminal act of corruption [3].

In the big Indonesian dictionary, gratification is defined to be giving money as prizes to employees outside the official salary; while in the legal dictionary, gratification that is derived from Dutch, gratificatie, or English, gratification is interpreted as a prize of money. Based on these two meanings, several important facts are observed. First, both in the Big Indonesian Dictionary and the legal dictionary, gratification is defined as giving gifts in the form of money. Secondly, the definitions of gratification in both dictionaries are neutral. It means gratification is not a disgraceful or negative act. Thirdly, the object of gratification in the sense of the Big Indonesia Dictionary is clearly aimed at employees, while in the legal dictionary, the object of gratification is not determined.

Furthermore, Eddy O.S. Hiariej [3] said that:

The term gratification is clearly found in Article 12B and Article 12C of Law Number 31 of 1999 as amended by Law Number 20 of 2001 concerning Eradication of Corruption Crime. In order to be unbiased, the two articles are cited in full as follows: Article 12B Paragraph (1), Every gratification toward a civil servant or state administrator in relation to his position and opposing his obligations or duties is considered as a bribery, with the following provisions: a. if the value is Rp. 10,000,000.00 (ten million rupiahs) or more, the verification that gratification is not bribery will be carried out by the recipient of the gratification; b. if the value is less than Rp. 10,000,000.00 (ten million rupiah), the verification of gratification is carried out by the public prosecutor. Paragraph (2), Criminal punishment for civil servants or state administrators as referred to Paragraph (1) is a sentence of life imprisonment or minimum of 4 (four) years imprisonment and a maximum of 20 (twenty) years imprisonment, and a criminal fine of at least Rp. $200,000,000.00$ (two hundred million rupiahs) and a maximum of Rp.1,000,000,000.00 
(one billion rupiahs). The provisions of Article 12C Paragraph (1) state that the provisions referred to Article 12B Paragraph (1) do not apply if the recipient of gratification reports the received gratification to the Corruption Eradication Commission. The report must be done by the recipient of gratification no later than 30 (thirty) working days from the date the gratification is received. Article 12C Paragraph (3) states that the Corruption Eradication Commission, for at least 30 (thirty) working days from the date of receiving the report, must stipulate that gratification can be the property of the recipient or the state. Based on the construction of the two articles, several important rules should be understood. First, gratification is basically not a crime. Second, gratification is considered a criminal act, which is equal to bribery, if relating to someone's position as well as contrasting to his/her obligations or duties. Strictly speaking, if gratification is not related to someone's positions and not opposed to their obligations or duties, receiving gratification is a lawful act.

The causes of gratification in match fixing case involving PSSI management are:

1. The football club pride factor to defeat PSSI in 1998 which was carried out by Persebaya club (Bajul Ijo force / green force); at that time Persebaya relented with a score of 0-12, known as sepakbola gajah.

2. Football gambling factor

3. Non-technical factors carried out by the referee who leads the match by making strange decision which is more beneficial for one team, which is considered normal in football matches.

4. Dual positions in Indonesian football.

\subsection{Prevention and Countermeasures Effort in Match Fixing}

Crime of Bribery in the formulation of the United Nations Convention Against Corruption is always followed by key elements, namely: a. act or refrain from acting in the execution of his official duties; b. Trading in influence; c. misappropriation of influence; d. Abuse of functions; e. Trading in influence; and f. Illicit enrichment. Looking at that convention substance, gratification isn't mentioned in this provision, the rule covers on bribery. The meaning extension of bribery in the Indonesian Corruption Acts brings up criminal acts of gratification [4].

As it is known that the definition of gratification in Article 12 of Law No. 20 of 2001 gratification is categorized as criminal acts when dealing with positions, so based on this, gratification is equal with bribery. On the contrary, if not related to position, then receiving gratification is not a crime.

Match fixing that occurs in football league whether at national or international levels is closely related to gratification (which can be categorized as corruption and bribery), because in setting such match fixing, facilities in the form of money and services are provided to correlated parties, such as managers of football clubs, referees, disciplinary committees, also PSSI committees.

The interesting part of Football Match Fixing in Indonesia some time ago which its gratification is categorized as criminal act since the acts were carried out by PSSI committees, the Referee, PSSI Disciplinary Committees and so on. 
Along with the rapid development of technology and information, acts of gratification transforms into various forms. Gratification can be done both at home and abroad, either through electronic media, money orders and other. Even the act of gratification may be carried out at inappropriate time, for example on Eid al-Fitr, wedding parties, birthdays, travel trips. The acts are connected to position of the recipient and sender of gratification. This appears in football Match Fixing in Indonesia.

Gratification creates an ambiguous assumption whether the gift is based on gratitude for a friendship, or the gift is as purely conscious intention of the gratification provider to obtain his/her wishes. Normatively, the last is included in criminal offense that is naturally against formal law as well as material law. This arises as a result of acts of gratification which have entered the moral and ethical domain of officials, thus system reform should be performed.

One of gratification cases in Football match fixing in Indonesia was held in October 2014; PSS Sleman match against PSIS Semarang in League 2 was considered showing sepakbola gajah.

The efforts to prevent the occurrence of gratification in match fixing are:

First, match fixing disclosure must be carried out by the police and the mass media. In this case, mass media acts as a tool that reveals the occurrence of match fixing, while the police as investigators who back up mass media to reveal such crime and law enforcement in eradicating match fixing.

Second, the effectiveness of legal protection toward witnesses and victims of match fixing, including legal protection for Whistleblowers. In an effort to enforce the law and eradicate match fixing, Chief of the Indonesian National Police Decree No. Pol: Sprin / 3678 / XII / HUK.6.6. / 2018 on December 21, 2018 concerning the Establishment of the Football Anti Mafia Police Task Force. With the establishment of the Football Anti Mafia Police Task Force, call center facilities are provided, which guarantee the confidentiality of the reporter's identity and this force is ready to strike first.

Third, the tournament should be arranged better. In general, match fixing occurs in matches that are considered as minor matches, the matches which the competed teams avoid potential opponents in the knockout phase matches. One solution that can be used is the use of half competition to minimize gratification on match fixing.

Fourth, improving the transparent campaign towards the perpetrators of gratification is done by introducing the league officials and elected team officials to prospective corruptors. If the corruptor does not immediately approach the authorities, corruptors will face punishment.

Fifth, there should be payment delay for officials of the league and teams, players, referees, team administrators, disciplinary committees involved in match fixing.

Sixth, the parties involved in match fixing are prohibited from being involved in matches for the rest of life. The policy that must be taken should be "one strike you are out" (once guilty, you will immediately be punished without warning).

Seventh, there must be a ban on dual positions between officials and federation officials. This dual position enables the emergence of match fixing, so it must be eliminated even banned.

\section{Conclusion}

Based on the above explanation, it can be concluded as (a) Match Fixing in Football occurs due to the involvement of several parties such as: league officials, football club 
officials, players, the presence of dual positions and the involvement of bookies, (b) 2. There is no strong legal basis in handling match fixing.

\section{References}

[1] Andi Hamzah, Pemberantasan Korupsi, Raja Grafindo Persada : Jakarta. 2005

[2] Muzadi, H. Menuju Indonesia Baru, Strategi Pemberantasan Tindak Pidana Korupsi. Bayu Media Publishing : Malang. 2004

[3] Eddy O.S. Hiariej, Memahami Gratifikasi (article) published by Kompas, June 13, 2011 edition.

[4] Andi Mulyono, Pengaruh Aspek Kultur Hukum Terhadap Perkembangan Andi Mulyono Tindak Pidana Gratifikasi di Indonesia, Jurisprudentie (Law Journal) Volume 3 Number December 2, 2016 